Article

\title{
Rapid Domoic Acid Depuration in the Scallop Argopecten purpuratus and Its Transfer from the Digestive Gland to Other Organs
}

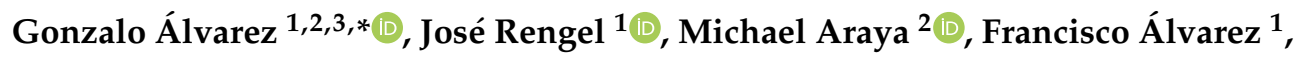 \\ Roberto Pino ${ }^{1,3}$, Eduardo Uribe ${ }^{1,3}$, Patricio A. Díaz ${ }^{4}{ }^{\circledR}$, Araceli E. Rossignoli ${ }^{5}$, \\ Américo López-Rivera ${ }^{6}$ and Juan Blanco ${ }^{5, *(D)}$ \\ 1 Facultad de Ciencias del Mar, Departamento de Acuicultura, Universidad Católica del Norte, \\ Coquimbo 1281, Chile; jose.rengel@ucn.cl (J.R.); falvarezsego@gmail.com (F.Á.); \\ roberto.pino@alumnos.ucn.cl (R.P.); euribe@ucn.cl (E.U.) \\ 2 Centro de Investigación y Desarrollo Tecnológico en Algas (CIDTA), Facultad de Ciencias del Mar, \\ Universidad Católica del Norte, Coquimbo 1281, Chile; mmaraya@ucn.cl \\ 3 Doctorado en Acuicultura, Programa Cooperativo Universidad de Chile, Universidad Católica del Norte, \\ Pontificia Universidad Católica de Valparaíso, Coquimbo 17811421, Chile \\ 4 Centro i mar \& CeBiB, Universidad de Los Lagos, Puerto Montt 557, Chile; patricio.diaz@ulagos.cl \\ 5 Centro de Investigacións Mariñas (Xunta de Galicia), Apto. 13, 36620 Vilanova de Arousa, Pontevedra, \\ Spain; araceli.escudeiro.rossignoli@xunta.gal \\ 6 Laboratorio de Toxinas Marinas, Instituto de Ciencias Biomédicas, Facultad de Medicina, \\ Universidad de Chile, Santiago 1027, Chile; amlopez@med.uchile.cl \\ * Correspondence: gmalvarez@ucn.cl (G.Á.); juan.carlos.blanco.perez@xunta.gal (J.B.); \\ Tel.: +56-51-2209766 (G.Á.)
}

Received: 23 September 2020; Accepted: 29 October 2020; Published: 3 November 2020

check for updates

\begin{abstract}
Domoic acid (DA), the main toxin responsible for Amnesic Shellfish Poisoning, frequently affects the marine resources of Chile and other countries across the South Pacific, thus becoming a risk for human health. One of the affected resources is the scallop Argopecten purpuratus. Even though this species has a high commercial importance in Northern Chile and Peru, the characteristics of its DA depuration are not known. In this work, the DA depuration was studied by means of two experiments: one in controlled (laboratory) and another in natural conditions. All organs of A. purpuratus depurated the toxin very quickly in both experiments. In some organs, an increase or a very small decrease of toxin was detected in the early depuration steps. Several models were used to describe this kinetics. The one that included toxin transfer between organs and independent depuration from each organ was the model that best fit the data. It seems, therefore, that the DA in this species is quickly transferred from the digestive gland to all other organs, which release it into the environment. Physiological differences in the two experiments have been shown to have some effect on the depuration from each organ but the actual reasons are still unknown.
\end{abstract}

Keywords: ASP; amnesic shellfish poisoning; detoxification; Northern Chile; toxicokinetics; modeling

Key Contribution: The domoic acid depuration kinetics in Argopecten purpuratus have been described and modelled. The toxin transfer from the digestive gland to other organs can explain the increase observed in some of them during the early depuration phases, which has been detected in this and other fast depurating species. 


\section{Introduction}

Domoic acid (DA) is a naturally produced algal toxin that accumulates in shellfish and is responsible for causing amnesic shellfish poisoning (ASP) [1]. The first intoxication in humans occurred in Prince Edward Island, Canada, in 1987, where more than 100 people became ill after consuming blue mussels [2]. The main symptoms of this intoxication include nausea, gastroenteritis, and vomiting, followed by neurological signs such as confusion, lethargy, disorientation, paresthesia, short-term memory loss, and in extreme cases, death (reviewed by [3]). Since the report of the first outbreak detected in Canada produced by the diatom Pseudo-nitzschia multiseries [2], episodes of this type of toxicity have been recorded in many areas around the world (reviewed in [4-6]).

In northern Chile, within the framework of the Molluscan Shellfish Safety Program of the National Fisheries and Aquaculture Service (SERNAPESCA), elevated levels of DA have been detected in shellfish from many of the primary aquaculture sites [7]. In some cases, the DA concentrations exceeded the regulatory limit $\left(20 \mathrm{mg} \mathrm{kg}^{-1}\right)$, and the harvesting of scallops from aquaculture sites was banned [8,9]. The longest and most intense ASP episode detected thus far occurred in the scallop culture area of Bahía Inglesa, in the austral spring of 2006. The bloom associated with this event was dominated by the DA-producing diatom Pseudo-nitzschia australis which reached a maximum concentration of $1.6 \times 10^{6}$ cells $\mathrm{L}^{-1}$ ( $80 \%$ of the total phytoplankton biomass) on November 2 2006. DA concentrations in the scallops were as high as $103 \mathrm{mg} \mathrm{kg}^{-1}$ wet weight, the maximum concentration of DA measured in scallops (Argopecten purpuratus) from this area (reviewed in [10]). During Pseudo-nitzschia blooms, scallops can accumulate sufficient DA to exceed the regulatory limit [11]. In bivalve tissues, the accumulation process depends on several factors, such as the presence and ingestion of toxic Pseudo-nitzschia species, the cell toxin content [4], as well as the balance of the physiological mechanisms regulating DA accumulation and depuration [12-15]. Depuration is the main process regulating maximal DA concentrations in shellfish and how long after the shellfish have ceased feeding on toxic phytoplankton before they are safe for human consumption [13,16-19].

Numerous studies have been undertaken to develop improved strategies for mitigating the negative consequences of ASP outbreaks. Among this are studies to determine accumulation and depuration of DA in different shellfish. This data are critical for developing kinetic models that allow government monitoring agencies, producers, or fishers to predict how fast shellfish can became toxic, and afterwards, how they will remain toxic $[17,20,21]$. Two depuration models have generally been used to describe the depuration process in bivalves. The first model is a one-compartment model characterized by an exponential decrease of DA content throughout the entire depuration period. This model has been shown to describe the depuration kinetics of the mussel Mytilus edulis adequately [22], and the scallops Placopecten magellanicus [15], and Pecten maximus [23]. The second model corresponds to a two-compartment model, characterized by rapid toxin elimination in the initial phase of depuration followed by a period of slower toxin elimination. This type of depuration has been reported in the mussels Volsella modiolus [24], Mytilus galloprovincialis [12], the razor clam Siliqua patula [25,26], the surf clam Mesodesma donacium [17], and the oyster Crassotrea virginica [13].

Other studies have been focused on developing specific treatments to reduce or eliminate the toxins from edible tissues of shellfish considering their inter-individual and the anatomical distribution of DA $[17,23,27-33]$. In the case of Pecten maximus, a species that retains domoic acid for a substantial period of time $[23,27,34]$, studies on the anatomical distribution of DA allowed the implementation of an exemption to the general regulation of the European Community for toxins in bivalve mollusks (European Decision 2002/226/EC), which made harvesting and marketing eviscerated scallops affected by domoic acid possible under special conditions. For this species the DA concentration in the entire mollusk must be less than $250 \mathrm{mg} \mathrm{kg}^{-1}$ and less than $4.6 \mathrm{mg} \mathrm{kg}^{-1}$ in each of the edible tissues (gonad and adductor muscle) $[35,36]$.

The scallop Argopecten purpuratus (Lamarck, 1819) is an endemic species of the Pacific coast of South America. It is distributed from Paita $\left(5^{\circ} \mathrm{S}\right)$ in northern Peru to Valparaíso $\left(33^{\circ} \mathrm{S}\right)$ in Chile $[37,38]$, dwelling in shallow ( $<30 \mathrm{~m}$ depth) sandy bays [39]. Currently, this scallop is one of the most important 
commercial species on international markets because of its high nutritional properties [40], relatively large size and fast growth rate [41,42], and high price [43]. Currently, Peru is the third most important scallop aquaculture producer worldwide, behind China, while Chilean scallop production stagnated in the 2000s and recently decreased $[41,43,44]$.

Even when several toxic outbreaks of DA have been detected in the primary A. purpuratus aquaculture sites in Northern Chile and presented a potential risk for Peruvian scallop aquaculture, no information is available on depuration of this toxin. In this work the kinetics of domoic acid depuration from different organs of A. purpuratus were studied. Mathematical models involving depuration and toxin transfer between organs were developed and implemented to understand the processes involved in depuration and to gain predictive capability.

\section{Results}

Two DA depuration experiments were carried out using scallops which had fed on a naturally occurring bloom of toxic Pseudo-nitzschia australis. In the first experiment, scallops were removed from the field, held in the laboratory, and fed non-toxic Isochrysis galbana (Haptophyta). Changes in body weight and tissue-specific DA concentration were then measured for 12 days. In the second, experiment the scallops were maintained in the field and allowed to feed naturally on a post-bloom phytoplankton population containing only a relatively small population of Pseudo-nitzschia australis.

\subsection{Experiment of Depuration of Domoic Acid in Controlled Conditions}

\subsubsection{Weight}

During the first laboratory experiment, there was a general, and statistically significant $(p=0.04)$, weight decrease, which took place in some of the body fractions studied. It was observed in DG (digestive gland), Mu (adductor muscle plus kidneys), and Go (gonad plus foot). The biomass of Ma (mantle) and Gi (gills) remained approximately constant throughout the experiment (Figure 1).

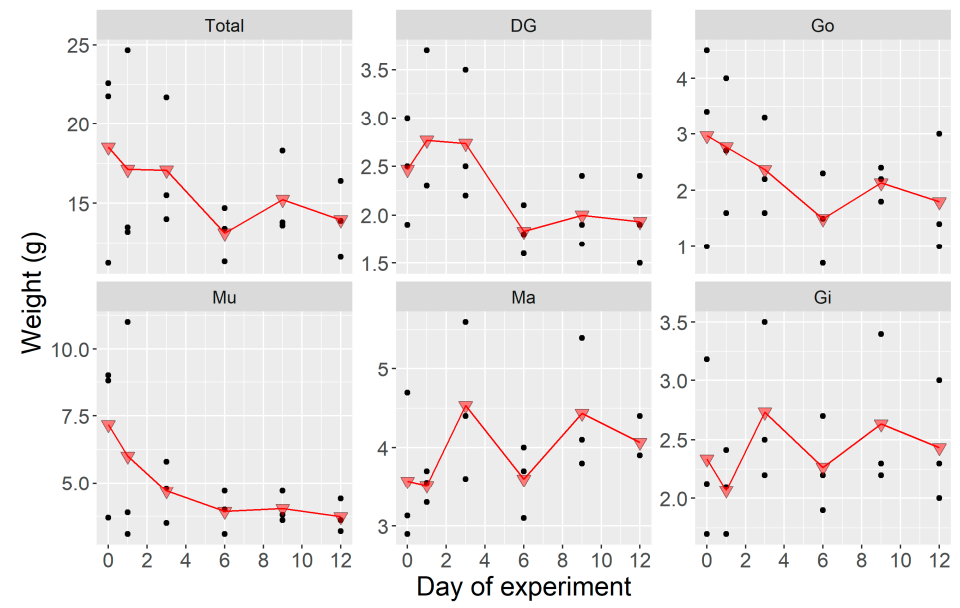

Figure 1. Weight of organs during the laboratory depuration experiment where Argopecten purpuratus were fed only the non-toxic Isochrysis galbana. Dots are the observed weights $(n=3)$ and triangles are their corresponding means. Total = all soft tissues, DG = digestive gland, Go =gonad + foot, $\mathrm{Mu}=$ adductor muscle + kidneys, $\mathrm{Ma}=$ mantle, $\mathrm{Gi}=$ gills .

\subsubsection{Toxin Burden}

Between day 0 and day 1 , the whole body of the scallops subjected to the laboratory conditions lost a small percentage of its toxin burden. In some organs, the loss was very small (Mu, Ma) or even nonexistent (Gi). After day 1, the burden decreased abruptly to residual levels in all organs but the mantle, where the decrease was more gradual (Figure 2). Only residual amounts of DA remained by day 3 to 6, depending on the organ. This rapid decrease in DA burden made it impossible to estimate 
the depuration rate using the data from the whole time series (Figure S1). Instead, the data from the first three days of sampling were used to calculate the depuration rate by fitting a first-order exponential decrease (Figure S2). The rate obtained was 0.91 day $^{-1}$ (which is equivalent to $60 \% \operatorname{loss}$ day $^{-1}$ ). The depuration from the different organs ranged from 0.3 day $^{-1}$ for Ma to 2.0 for Mu. Meanwhile, Gi, DG, and Go (in increasing order) had intermediate depuration rates $(0.7,0.9$, and 1.5 , respectively).

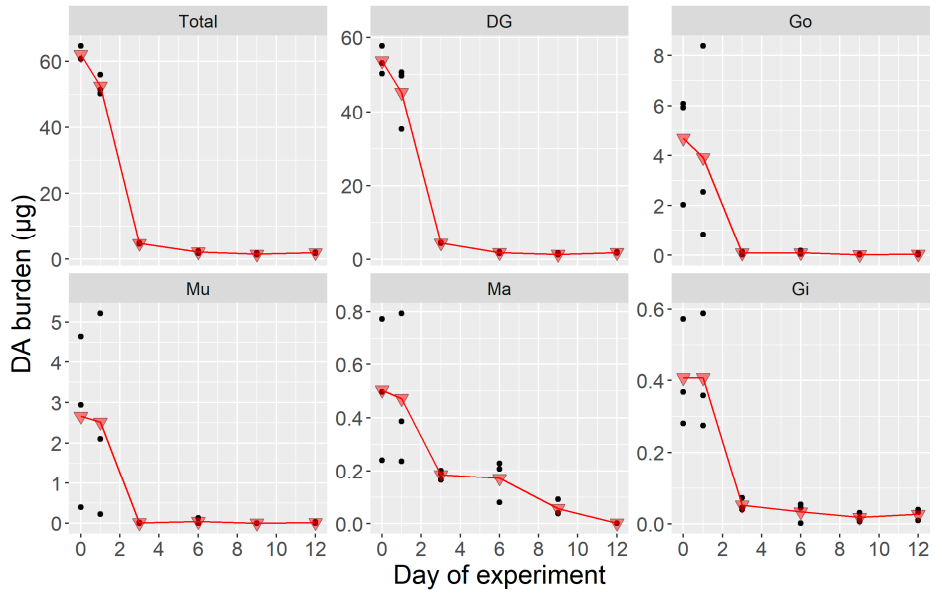

Figure 2. Tissue-specific domoic acid (DA) burden in the laboratory depuration experiment where Argopecten purpuratus were fed only the non-toxic Isochrysis galbana. Dots are the observed burden $(n=3)$, and triangles are their corresponding means. Total $=$ all soft tissues, DG $=$ digestive gland, $\mathrm{Go}=$ gonad + foot, $\mathrm{Mu}=$ adductor muscle + kidneys, $\mathrm{Ma}=$ mantle, $\mathrm{Gi}=$ gills.

\subsubsection{Whole Body and Tissue-Specific DA Concentrations During the Laboratory Experiment}

The changes in the tissue DA concentrations observed during the laboratory experiment were very similar to those of the burden. The concentration, both in the whole body and the individual organs, decreased quickly to residual levels (Figure 3). The concentration increased or was maintained from day 0 to day 1 in $\mathrm{Gi}$ and $\mathrm{Ma}$ (which lost almost no weight), but also in $\mathrm{Mu}$. In the Go, Ma, and $\mathrm{Mu}$, the decrease measured in day 6 was smaller than that which could be expected from the concentration recorded in day 3 . The estimated rate for the whole body was 0.9 day $^{-1}$. For the different organs, it ranged from 0.4 day $^{-1}$ in the mantle to 1.7 in $\mathrm{Mu}$, with intermediate rates for Gi, DG and Go (in ascending order).
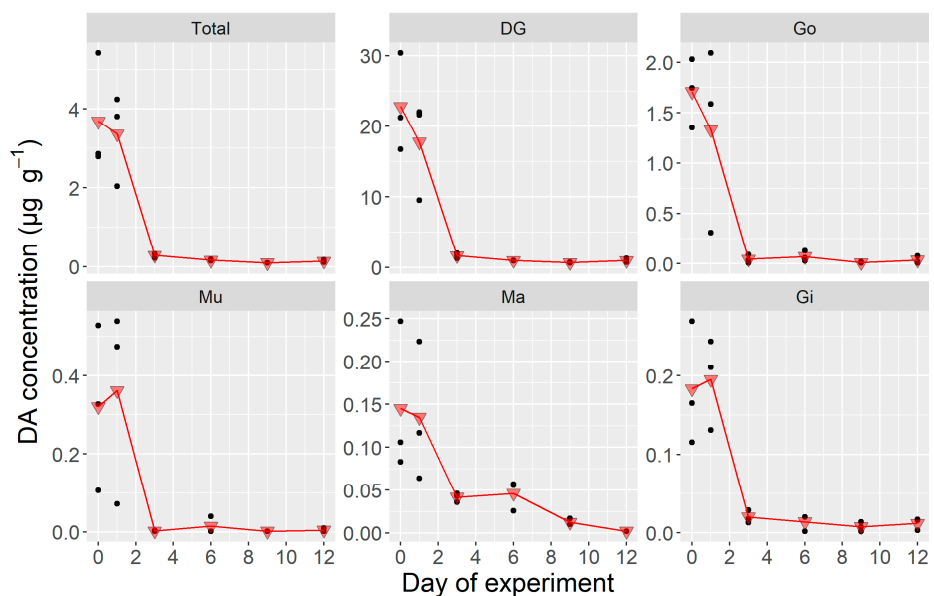

Figure 3. Organ-specific DA concentration in the laboratory depuration experiment where Argopecten purpuratus were fed only non-toxic Isochrysys galbana, dots are the observed burden $(n=3)$ and triangles are their corresponding means. Total = all soft tissues, DG = digestive gland, Go = gonad + foot, $\mathrm{Mu}=$ adductor muscle + kidneys, $\mathrm{Ma}=$ mantle, $\mathrm{Gi}=$ gills . 


\subsection{Experiment of Domoic Acid Depuration in the Natural Environment}

\subsubsection{Weight}

During the experiment carried out in natural conditions, there was a general, but non-significant $(p=0.07)$ weight increase (Figure 4$)$. Like in the laboratory experiment, the weight of Ma and Gi remained approximately constant, but those of Go and DG underwent changes, although in this experiment by contrast with the laboratory experiment, their weight increased. The increase was especially pronounced in Go $(p<0.0001)$. Mu maintained its weight throughout this experiment.

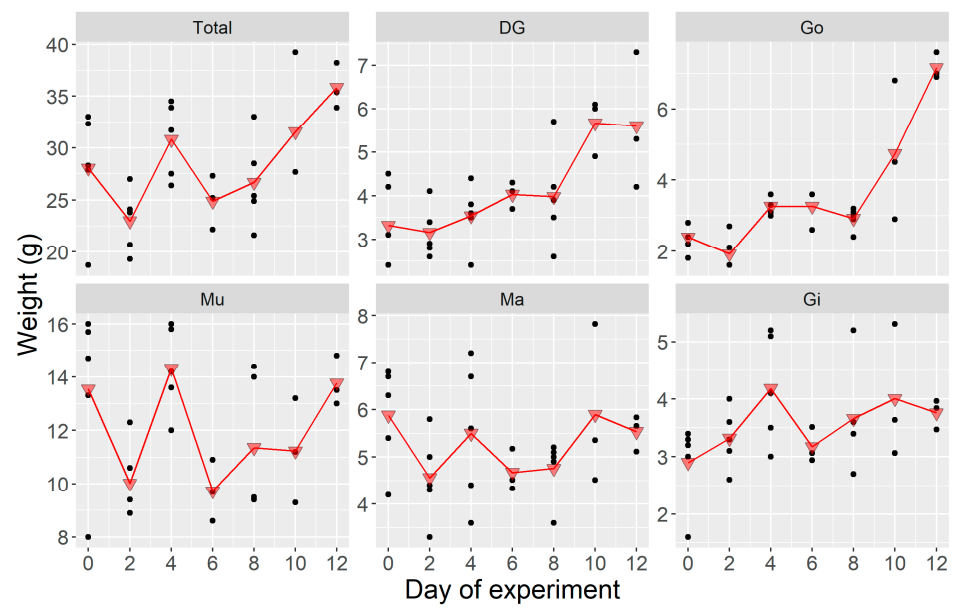

Figure 4. Weight of Argopecten purpuratus organs during the depuration experiment where shellfish were incubated in the field under natural conditions. Dots are the observed weights, and triangles are their corresponding means. Total = all soft tissues, DG = digestive gland, Go = gonad + foot, $\mathrm{Mu}=$ adductor muscle + kidneys, $\mathrm{Ma}=$ mantle, $\mathrm{Gi}=$ gills .

\subsubsection{Toxin Burden}

In natural conditions, the total DA burden continuously decreased with time in a nearly negative exponential way (Figure 5) (linear when logarithmically transformed (Figure S3 Supplementary Materials). This decrease was driven by DG and Mu, while Ma and Gi increased their DA content from day 0 to day 2 , and the gonad approximately maintained it until day 6 . After day 2 , the burden decreased in all organs but Go.
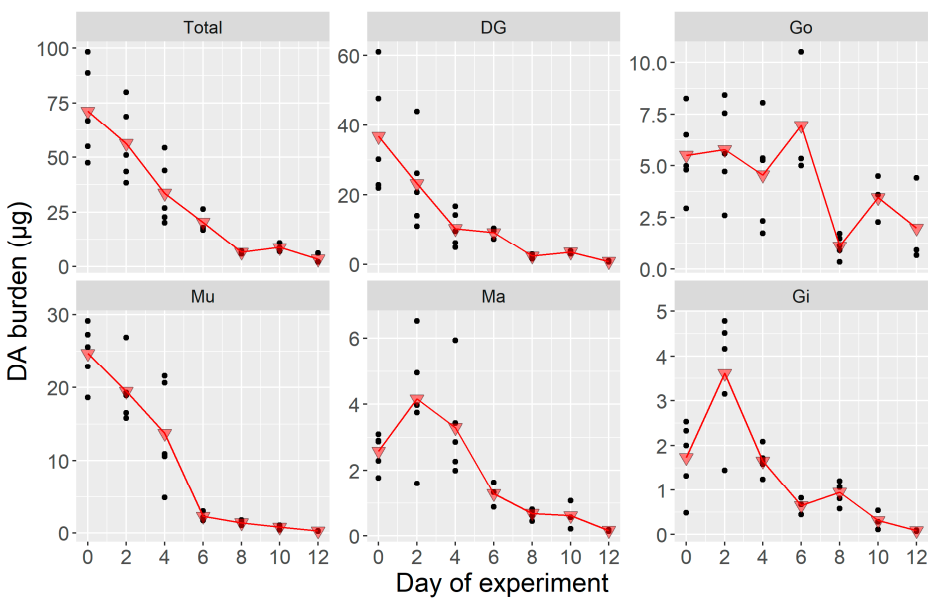

Figure 5. Domoic acid burden of Argopecten purpuratus organs during the depuration experiment where shellfish were maintained under natural conditions. Dots are the observed burden and triangles are their corresponding means. Total = all soft tissues, DG = digestive gland, Go = gonad + foot, $\mathrm{Mu}=$ adductor muscle + kidneys, $\mathrm{Ma}=$ mantle, $\mathrm{Gi}=$ gills. 
Scallops' depuration in these conditions was also fast, but not as fast as in the laboratory experiment. The whole body depurated at a rate (assuming the same kinetics as for the lab experiment) of $0.27 \mathrm{day}^{-1}$ (equivalent to $24 \%$ day $^{-1}$ ). The recorded differences between organs were also smaller, ranging from 0.12 day $^{-1}$ for Go to 0.40 day $^{-1}$ for the Mu. Gi, Ma, and DG had intermediate depuration rates (Figure S3, Supplementary Materials), with the first two depurating in a very similar way and more slowly than DG. Those estimates were similar to the ones obtained in the laboratory experiment with the main difference being the slower depuration of Go.

\subsubsection{Whole Body and Tissue-Specific DA Concentrations During the Field Experiment}

In the scallops depurated in natural conditions, the concentration of the whole body decreased in a first-order exponential way (linearly when logarithmically transformed (Figure S4, Supplementary Materials), but the observed level for day 2 was slightly higher than expected. The DG concentration (once transformed) decreased linearly without any noticeable deviation in day 2. In Gi, Ma, and Go, notwithstanding, the concentration increased during that day, and in $\mathrm{Mu}$, it was maintained (Figure 6).

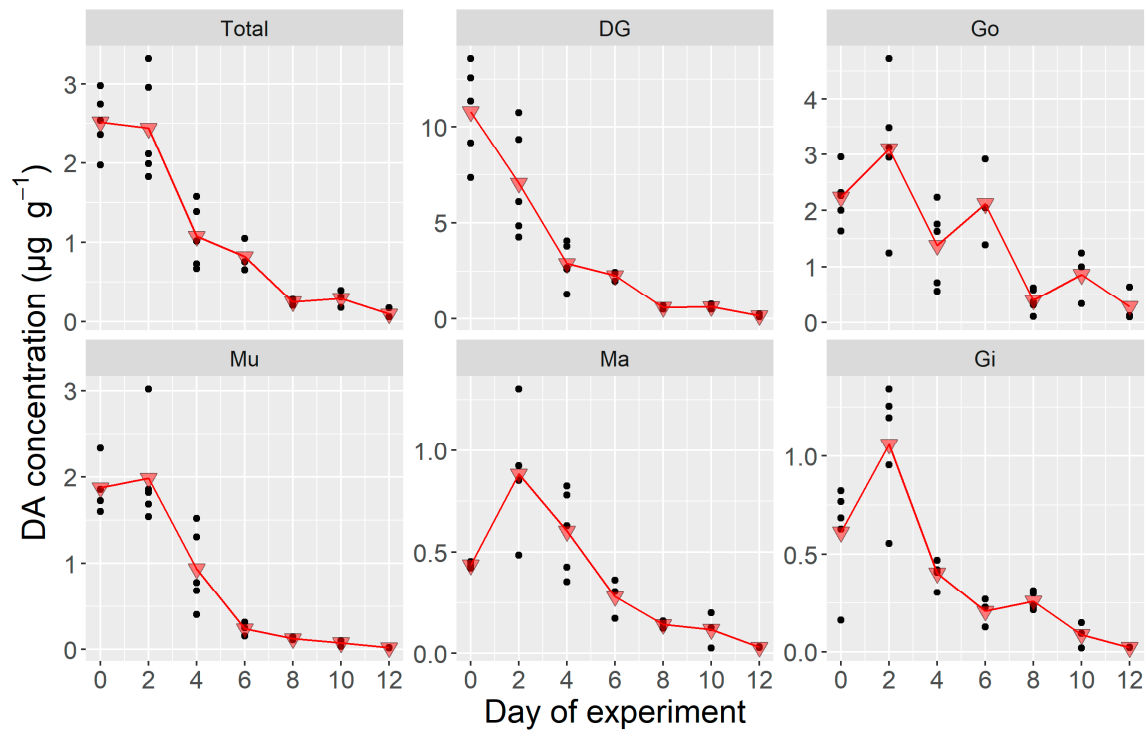

Figure 6. Organ-specific DA concentration in the field depuration experiment where Argopecten purpuratus were maintained under natural conditions. Dots are the observed burden, and triangles are their corresponding means. Total = all soft tissues, DG = digestive gland, Go = gonad + foot, $\mathrm{Mu}=$ adductor muscle + kidneys, $\mathrm{Ma}=$ mantle, $\mathrm{Gi}=$ gills .

The whole body depurated at a rate of $0.29 \mathrm{day}^{-1}$, substantially more slowly than in the experiment carried out in the laboratory. Mu was the body fraction with the highest depuration rate $\left(0.40\right.$ day $\left.^{-1}\right)$ and Go, the one with the lowest rate $\left(0.20 \mathrm{day}^{-1}\right)$. The other organs had intermediate rates, depurating DG noticeably faster than the two other organs (Figure S4, Supplementary Materials).

\subsection{Model Fitting}

\subsubsection{Depuration of Domoic Acid in the Natural Environment}

Two types of models were fitted to the experimental data of the toxin burden. The first one was first-order exponential decrease of each organ, without toxin transfer between organs, and the second included toxin transfers from DG to all other organs, which depurated in the same way than in the first type of model. When fitted to the data from the experiment carried out in natural conditions (the complete dataset) the model without transfers of DA from the digestive gland to other organs was unable to correctly describe the depuration, especially because of the increase of toxin burden in the second day of the experiment in some organs. When the transfer between organs was included, 
the model fits the observed data much better (Figure 7). The simplest model of this type, with only a common transfer rate to all organs and a common depuration rate, described the general shape of the kinetics but did not fit well the levels of DA in several organs, especially in DG (with levels noticeably underestimated).
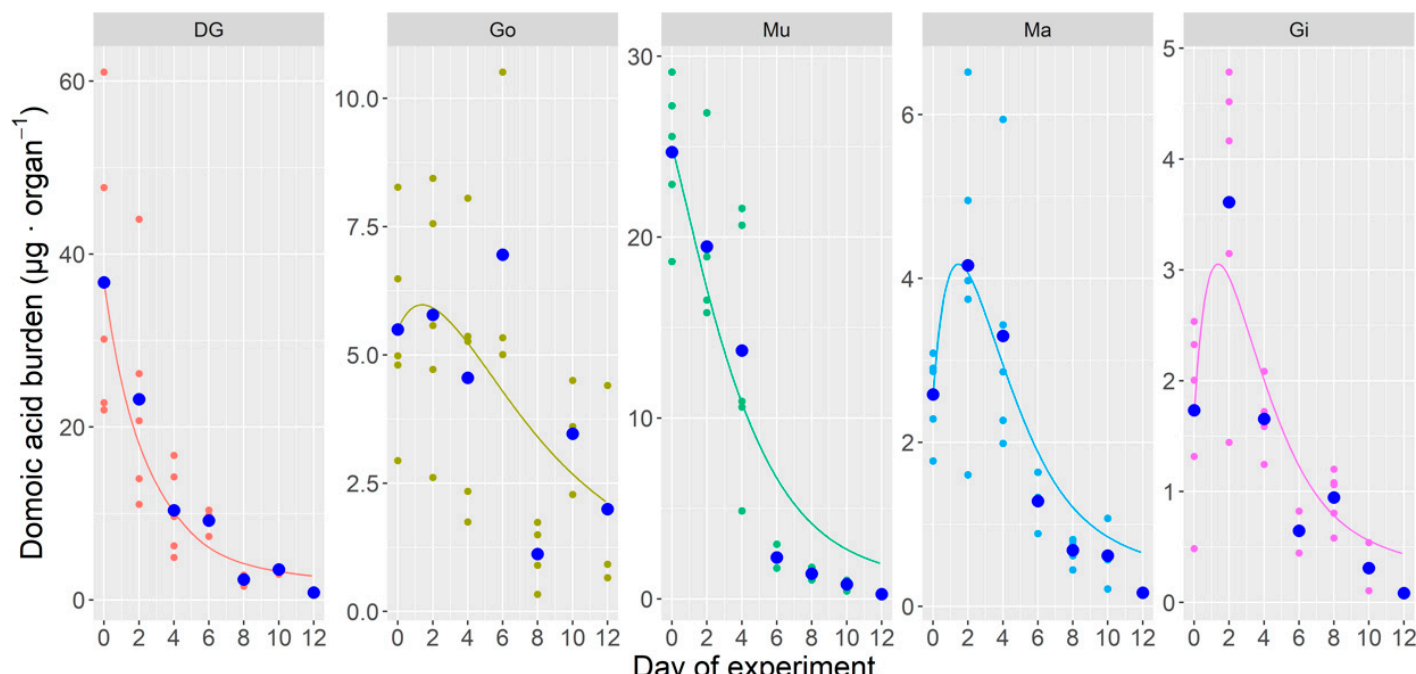

Figure 7. Multi-compartment model fit to the toxin burden data obtained in the DA depuration experiment in natural conditions. Small dots are the obtained data, large dots are their means, and lines are the output of the model. $\mathrm{DG}=$ digestive gland, $\mathrm{Go}=$ gonad + foot, $\mathrm{Mu}=$ adductor muscle + kidneys, $\mathrm{Ma}=$ mantle, $\mathrm{Gi}=$ gills.

When different depuration rates were allowed for the digestive gland and all other organs, a better fit was obtained. The improvement, notwithstanding, was not large. The new model only fit slightly better the data of DG and Ma, with no improvement in the other tissues. When the transfer rates and the depuration rates were allowed to vary, the fitting improved, but some aspects of the kinetics were still not correctly described. The DA levels in DG are slightly underestimated, and the final part of the depuration curve of $\mathrm{Mu}$ is overestimated. The actual fitting of the Go cannot be correctly evaluated because of its high dispersion. The lowest depuration rate estimated by the model is that for DG, and the two highest were those of $\mathrm{Gi}$ and Ma. The transfer rates of the toxin were also the highest for those two organs (Table 1).

Table 1. Parameters of the fitted models which included transfer from the digestive gland to other organs.

\begin{tabular}{ccccc}
\hline \multirow{2}{*}{ Organ } & \multicolumn{2}{c}{ Natural Conditions } & \multicolumn{2}{c}{ Laboratory Conditions } \\
\cline { 2 - 5 } & Depuration Rate & Transfer Rate & Depuration Rate & Transfer Rate \\
\hline DG & 0.03806 & & 0.095 & \\
Gonad & 0.229144 & 0.06657 & 3.272 & 0.336 \\
Mantle & 0.524622 & 0.10365 & 0.504 & 0.005 \\
Gill & 1.424803 & 0.24322 & 4.202 & 0.048 \\
Muscle & 0.33993 & 0.1412 & 4.201 & 0.286 \\
\hline
\end{tabular}

\subsubsection{Depuration of Domoic Acid in Laboratory}

The same model fitted to the data obtained in the laboratory gave different estimates, but the amount of useful observations was very low because of the steep toxin burden descent (Figure 8). The model estimates some transfer of toxin, but the organs to which the toxin transfer was estimated to be higher did not coincide with those in the experiment carried out in natural conditions (Table 1). Some of the observed differences could be explained if the depuration of the different organs does take place totally or partially through the kidney; unfortunately, it was not separated from the adductor 
muscle in any of the experiments. This may account for the increase of DA in Mu (adductor muscle plus kidney) during the initial steps of the laboratory experiment, in which the depuration rate was very high.

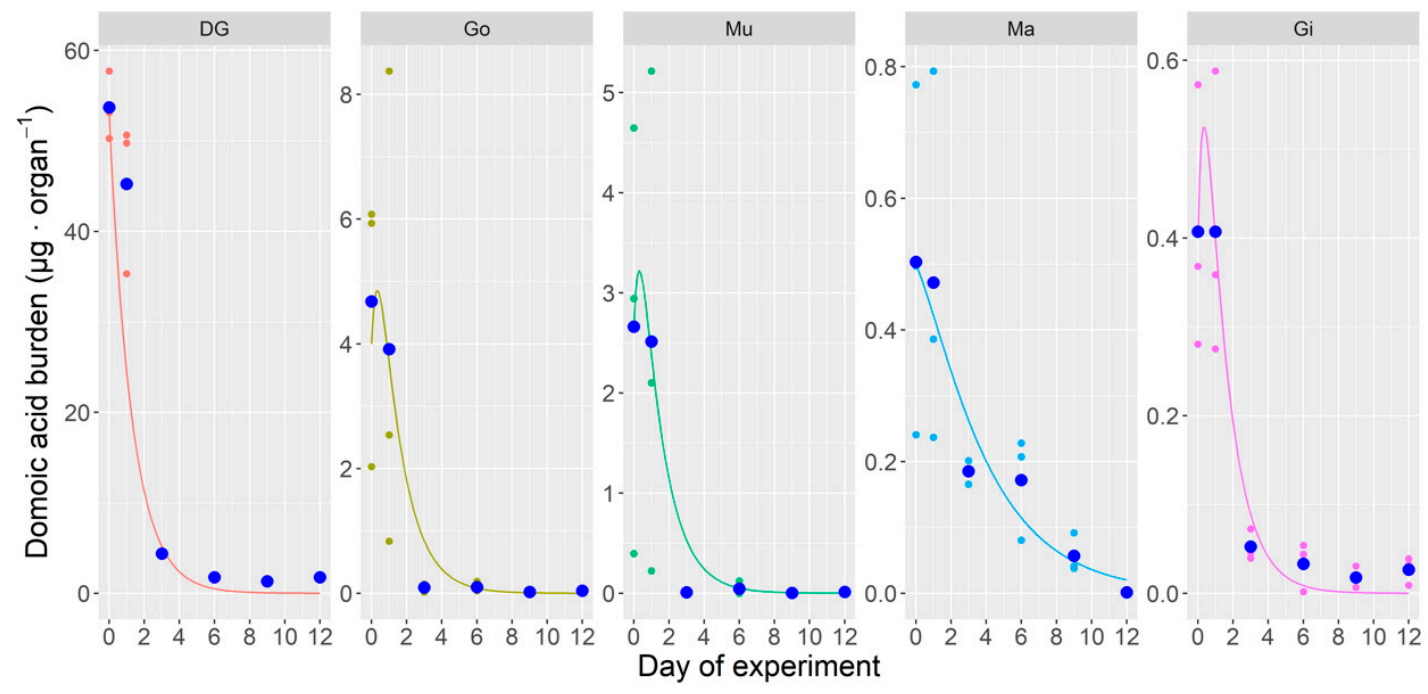

Figure 8. Multi-compartment model fit the toxin burden data obtained in the domoic acid depuration experiment done in the laboratory. Small dots are the obtained data; large dots are their means, and lines are the output of the model. DG = digestive gland, $\mathrm{Go}=$ gonad + foot, $\mathrm{Mu}=$ adductor muscle + kidneys, $\mathrm{Ma}=$ mantle, $\mathrm{Gi}=$ gills.

\section{Discussion}

\subsection{Physiological Conditions in the Two Experiments}

During the experiment carried out in the laboratory, where the food availability was approximately $120 \mathrm{~mm}^{3}$ day $^{-1}$, the scallops underwent weight loss. Some organs were not affected by that decrease (gill and mantle), but all the others were, especially the adductor muscle and the digestive gland. The resources stored in several organs were therefore used to maintain their metabolism. Scallops usually accumulate nutrient reserves during periods of somatic growth when food is abundant. Among them, glycogen in adductor muscles is the principal source of energy, but protein stored in the same organ and lipids in the digestive gland also play important roles during starvation periods (reviewed by [45]). The opposite situation took place in the scallops from the natural environment. In this case, the abundance of phytoplankton was high $\left(>1,000,000\right.$ cell $\left.\mathrm{L}^{-1}\right)$ and the estimated food availability was much higher than in the laboratory experiment, with an average of $3200 \mathrm{~mm}^{3} \mathrm{day}^{-1}$. As a consequence, the food was enough not only for maintenance but also to support some growth and gonadal development.

\subsection{Domoic Acid Depuration}

In both experiments, domoic acid depuration was very fast, independently from how it was measured (decrease of toxin burden or concentration). This species should, therefore, be considered to be a fast depurating one, as is also the case for several mytilids, such as Mytilus edulis, M. galloprovincialis, M. californianus, and other species like the clam Mya arenaria [24]. In the laboratory experiment, after the fast-initial decrease of DA, the scallop organs maintained a very low amount of the toxin until the end of the experiment. Residual amounts have been also found in other species whose depuration follows a two-compartment kinetics, like Volsella modiolus [24], Placopecten magellanicus [20], Mytilus galloprovincialis [12], M. edulis, Crassostrea virginica [13], and Mesodesma donacium [17].

There were important differences in the apparent depuration rate between the two experiments. Scallops in laboratory depurated faster than in natural conditions ( 0.91 vs. 0.27 day $^{-1}$, respectively). 
Most of the difference is probably due to some degree of reintoxication in natural conditions, because the toxic algae populations had not completely disappeared (Table S1, Supplementary Materials). The two experiments also differed at least in temperature and food availability, and both could have contributed to the observed difference. The difference in the temperature at which the experiments were developed $\left(16{ }^{\circ} \mathrm{C}\right.$ in the laboratory and $13-14{ }^{\circ} \mathrm{C}$ at natural conditions) could have contributed to the difference in depuration rate, since temperature seems to accelerate the DA depuration in other species, like the king scallop Pecten maximus [27] or the detoxification of paralytic shellfish toxins in the visceral mass of the surf clam Spisula solidissima [46]. The magnitude of the recorded difference seems, nevertheless, too high to be the only factor, as the estimated Q10 (temperature coefficient) is near 6, while, for most physiological rates in bivalves it is between 2 and $3[47,48]$. Food availability would not seem to be primarily responsible because in sight of its likely negative effect on depuration in the king scallop, Pecten maximus [27]. Nevertheless, its effect cannot be ruled out because the physiological differences between the two species could be important.

\subsection{Domoic Acid Depuration Kinetics}

The depuration kinetics in the two experiments were not the same. The toxin levels in the laboratory experiment dropped very quickly to a residual level (less than $0.5 \%$ of the regulatory limit) which was maintained until the end of the experiment with small variations. A two-compartment model for each organ can therefore describe it. However, from a practical point of view, the second compartment would be negligibly small, and the kinetics could be described by an initial ( 3 days) exponential decrease and a subsequent stabilization at nearly residual levels. The same situation was observed by Mafra Jr et al. [49].

In natural conditions, the depuration rate was slower (not extremely fast) and the residual levels which characterized the final part of the depuration period were not reached. The kinetics of the DA in each organ can therefore be described by a one-compartment model. The generally good fitting of a straight line to the logarithmically transformed DA burden and concentration indicates that the depuration follows a first-order exponential decrease. Even when the presence of toxic phytoplankton and the consequent re-intoxication could have been expected to alter the exponential kinetics, no effect can be appreciated. The most likely reason is that the decrease of the toxic phytoplankton during the experiment was also approximately exponential (with a decrease rate of 0.17 day $^{-1}$ ) (Table S1, Supplementary Materials).

The depuration of some organs did not completely follow the expected curve in either experiment. The toxin in some organs did not decrease at the expected rate or even increased between the first and second days of the experiment. As DA is acquired mostly with the ingested phytoplankton, it seems that a quick redistribution of the toxin among all organs took place. The multi-compartmental model fitted to the data, allowing the transfer from the digestive gland to all other organs and the independent depuration of each of them, describes the main characteristics of the observed depuration very well. This suggests that the hypothesized transfer actually takes place and that the depuration from the organs is very fast. With the obtained data it is not possible to discern whether the depuration from the organs took place directly or by transfer in the hemolymph to excretory organs, such as the kidney. It seems, nevertheless, that the later could be the main depuration route for several reasons. First, it is unlikely that the high depuration rate of $\mathrm{Mu}$ is due to the adductor muscle, which has a low surface/volume ratio, and consequently, a low rate of exchange with the surrounding water. Second, a multicompartment model similar to Model II (2), but modified to simulate the kinetics of the adductor muscle and the kidney separately, and by assuming that all depuration takes place only through the digestive gland and the kidney, fit much better with the data of $\mathrm{Mu}$ in the experiment carried out in natural conditions. However, with that model the fittings obtained for the digestive gland were worse that the ones obtained with Model II (2), indicating that some aspects of the kinetics have not been correctly implemented and suggesting that new experiments should be carried out to unequivocally ascertain the actual excretion route. 
The fast depuration rate estimated for Mu could be explained by the fact that the adductor muscle contains a large amount of hemolymph in venous sinuses and an important artery [50]. This organ is in fact the most adequate one to extract hemolymph from bivalves [51]. DA transfer from visceral to other tissues through the circulatory system has been suggested in the oyster Crassostrea gigas [52].

Currently, little information exists regarding the distribution of DA from the digestive gland (or visceral tissues) to different organs in other bivalve species. The information that exists indicates this distribution process is a species-specific characteristic. Mafra et al. [13] suggested that the faster DA elimination in visceral tissues of M. edulis and C. virginica could be explained by toxin transfer to other tissues. In the king scallop Pecten maximus DA redistribution seems to be very limited, and restricted to post-spawning periods [23]. In other species, such as the scallop Placopecten magellanicus, [20] and the mussel M. edulis [13] the toxin has a preferential accumulation in the digestive gland, and there is no evidence if the DA exchange among tissues is relevant in toxin elimination. On the contrary, the anatomical distribution in other species suggests that the redistribution could be an important process in some cases. In C. virginica, during the initial days of the toxin accumulation phase a large proportion of DA can be redistributed from visceral to other tissues [13]. Similarly, during the uptake phase in the surf clam Mesodesma donacium, toxin was evenly distributed among the soft tissues [17].

Finally, considering the high depuration rate, the time in which the bivalves are unsafe for consumers once the toxic algae populations have disappeared is very short, and therefore the economic losses that could result by the ASP outbreaks in the scallop aquaculture industry should be moderate.

\section{Conclusions}

Argopecten purpuratus is a rapid domoic acid depurator (less than 3 days to depurate $50 \%$ of the toxin). The toxin acquired by the digestive gland was quickly transported to other organs, which in some cases increased its DA content during the initial phases of the depuration. The depuration of the DA from all organs seems to approximately follow a first-order exponential decay, but a residual amount of the toxin was slowly depurated. It seems very likely that most of the excretion takes place through the main excretory organs (digestive gland and kidney). Physiological conditions seem to affect the depuration kinetics, but the way in which they act is unclear. Domoic acid should not be expected to have a relevant impact on the culture and exploitation of this species, unless toxic Pseudo-nitzschia blooms are very persistent in time.

\section{Materials and Methods}

\subsection{Depuration of Domoic Acid in Controlled Conditions}

Scallops (Argopecten purpuratus) naturally contaminated with ASP toxins were donated by Invertec Ostimar Company from a farm located in Bahía Tongoy during a Pseudo-nitzschia australis bloom detected at the end of July 2017. A sample of 40 commercial size individuals (shell height: $7.73 \pm 4.10 \mathrm{~cm}$ ) was collected and transported to the laboratory within a few hours after collection. Once in the laboratory, the scallops were distributed into six groups of five individuals. Each group was randomly assigned to one day of depuration in the experiment $(0,1,3,6,9$, and 12). Three scallops from the first group were used to determine the initial (day 0 ) concentration of domoic acid (DA). The remaining groups were distributed among 15-L plastic containers filled with filtered seawater $(1 \mu \mathrm{m})$ and continuous aeration. The containers were maintained at $16 \pm 1{ }^{\circ} \mathrm{C}$ in a temperature-controlled walk-in environmental chamber. Each group of scallops was fed twice a day with Isochrysis galbana at a final density of 600,000 cells $\mathrm{mL}^{-1}$, which represents, approximately, a biovolume of $120 \mathrm{~mm}^{3}$. Water was replaced daily with clean seawater to minimize re-ingestion of feces. On days 1, 3, 6, 9, and 12, three scallops corresponding to the assigned group were sampled for dissection and toxin analysis.

\subsection{Depuration of Domoic Acid in Natural Environment}

Scallop samples were maintained in the usual culture conditions in scallop culture lanterns at the facilities of Invertec Ostimar Company located in a farm in Bahía Tongoy, Chile. Scallops of and 
approximated valve height of $7 \mathrm{~cm}$ (which finally resulted in an average of $7.15 \pm 1.2$ ) were sampled every other day from 2 to 14 August 2017 (days 0, 2, 4, 6, 8, 10, 12). Each sample consisted of 3-5 individuals which were processed as in the previous experiment. In this experiment, the population of the DA producer species Pseudo-nitzschia australis was substantially reduced, but still present at low concentrations (Table S1. Supplementary Materials). Consequently, some low level DA uptake likely continued.

During the period in which the experiment developed, data of abundance of Pseudo-nitzschia, and the main phytoplankton species present, were obtained weekly by the Molluscan Shellfish Safety Programme (PSMB Programa de Sanidad de los Moluscos Bivalvos) of SERNAPESCA (www.sernapesca.cl) using a dividable hose sampler $(0-10 \mathrm{~m})$ and quantified by the method of Utermöhl [53]. Roughly, the biovolume of phytoplankton available for each scallop (assuming a clearance rate of $10 \mathrm{~L} \mathrm{~h}^{-1}$ [54] and computing the biovolumes following Olenina et al. [55]) ranged from 1000 to $7500 \mathrm{~mm}^{3}$ day $^{-1}$ with an average of 3200 . Additionally, water temperature was measured with a YSI 550A oxygen meter at 10-m depth. During the experiment the temperature ranged from 13 to $14{ }^{\circ} \mathrm{C}$.

\subsection{Scallop Dissection and Domoic Acid Analysis}

To determine domoic acid (DA) concentration and toxin burden, each individual was carefully dissected into the edible tissues corresponding to the gonad plus foot (Go), adductor muscle plus kidneys $(\mathrm{Mu})$, and the non-edible tissues, corresponding to the digestive gland (DG), mantle (Ma), and gills (Gi). Domoic acid was extracted from scallop tissues following the procedure described by Quilliam, et al. [56], while matrix effects and extraction efficiency were evaluated following the method described by Regueiro et al. [57] (for result see Table S2, Supplementary Materials). Extraction was performed from approximately $4 \mathrm{~g}$ of tissue homogenate with $16 \mathrm{~mL}$ of $\mathrm{MeOH} /$ water $(1: 1, v / v)$ using an Ultra-Turrax T25 dispersing system (IKA ${ }^{\circledR}$ Werke GmbH \& Co. KG, Staufen, Germany) at $11,000 \mathrm{rpm}$ for $3 \mathrm{~min}$. The extract was clarified by centrifugation at $5000 \times \mathrm{g}$ for $20 \mathrm{~min}$ (Centurion K2015R, Centurion Scientific Ltd., Stoughton, West Sussex, UK). A one-mL aliquot was filtered through a $0.2 \mu \mathrm{m}$ Clarinert nylon syringe filter (13 mm diameter) (Agela Technologies, Torrance, CA, USA) and stored in an autosampler vial at $-20^{\circ} \mathrm{C}$ until analysis.

The analysis was performed by LC-HRMS following the method described by Regueiro et al. [57] with modifications. The instrumental analysis was developed using a Dionex Ultimate 3000 UHPLC system (Thermo Fisher Scientific, Sunnyvale, CA, USA). A reversed-phase HPLC column Kinetex C18 $(50 \mathrm{~mm} \times 2.1 \mathrm{~mm} ; 2.6 \mu \mathrm{m})$ with an Ultra Guard column C18 both from Phenomenex (Torrance, CA, USA) was used. The flow rate was set to $0.20 \mathrm{~mL} \mathrm{~min}^{-1}$, and the injection volume was $10 \mu \mathrm{L}$. Mobile phases $\mathrm{A}$ and $\mathrm{B}$ were water and $\mathrm{MeOH} /$ water $(50 / 50, v / v)$, respectively, both containing $0.2 \%$ formic acid $(\mathrm{pH}=2.4)$. The following gradient was used to achieve the chromatographic separation: $100 \%$ phase A for $2 \mathrm{~min}$, decreased to $45 \%$ A over $2 \mathrm{~min}$, hold at $45 \%$ A for $3.4 \mathrm{~min}$, and then returned to initial conditions over $4.6 \mathrm{~min}$. The total analysis run time was $12 \mathrm{~min}$. The detection of domoic acid was carried out by a high-resolution mass spectrometer $Q$ Exactive Focus equipped with an electrospray interphase HESI II (Thermo Fisher Scientific, Sunnyvale, CA, USA). The interface was operated in positive ionization mode with a spray voltage of $3.5 \mathrm{kV}$. The temperature of the ion transfer tube and the HESI II vaporizer were set at $250{ }^{\circ} \mathrm{C}$. Nitrogen $(>99.98 \%)$ was employed as sheath gas and auxiliary gas at pressures of 20 and 10 arbitrary units, respectively. The data were acquired in selected ion monitoring (SIM) and data-dependent $\left(\mathrm{ddMS}^{2}\right.$ ) acquisition modes (for quantification and confirmation, respectively). In SIM mode, the mass was set to $312.1445 \mathrm{~m} / \mathrm{z}$, using a mass resolution of 70,000. DA was quantified by external calibration, using a DA certified reference solution (CRM-DA-g) (NRC, CNRC, Canada). The limit of quantification of the method was $2 \mathrm{ng} \mathrm{mL}^{-1}$ and the recoveries ranged from 97 to $117 \%$. Some DA isomers, with retention times different from DA were also detected by this method but because of their limited toxicological interest and low transformation to or from DA (Tables S3 and S4, Supplementary Materials) they have not been included in this study. 


\subsection{Modelling}

Two models were fitted to the obtained data. The simplest one, Model I (1) was a first-order exponential decay of domoic acid burden in each organ.

$$
\frac{d\left(D A_{0}\right)}{d t}=-D R_{0} \times D A_{0}
$$

where $D A_{o}$ is the domoic acid burden in each organ (o), $\mathrm{DR}_{\mathrm{o}}$ the depuration rate corresponding to the organ $o$, and $t$ is the depuration time.

The second model used, Model II (2) also assumed a first-order exponential depuration in each organ, but it allows for toxin transfers from the digestive gland to all other studied organs.

$$
\begin{gathered}
\frac{d\left(D A_{D g}\right)}{d t}=-\mathrm{DR}_{\mathrm{Dg}} \times D A_{D g}-\Sigma \mathrm{TR}_{\mathrm{Dg}-0} \times D A_{D g}+\mathrm{K} \cdot \text { Cells }_{\mathrm{t}} \\
\frac{d\left(D A_{G o}\right)}{d t}=-\mathrm{DR}_{\mathrm{Go}} \times D A_{G o}-\mathrm{TR}_{\mathrm{Dg}-\mathrm{Go}} \times D A_{D g} \\
\frac{d\left(D A_{M a}\right)}{d t}=-\mathrm{DR}_{\mathrm{Ma}} \times D A_{M a}-\mathrm{TR}_{\mathrm{Dg}-\mathrm{Ma}} \times D A_{D g} \\
\frac{d\left(D A_{G i}\right)}{d t}=-\mathrm{DR}_{\mathrm{Gi}} \times D A_{G i}-\mathrm{TR}_{\mathrm{Dg}-\mathrm{Gi}} \times D A_{D g} \\
\frac{d\left(D A_{M u}\right)}{d t}=-\mathrm{DR} R_{\mathrm{Mu}} \times D A_{M u}-\mathrm{TR}_{\mathrm{Dg}-\mathrm{Mu}} \times D A_{D g}
\end{gathered}
$$

where subindices denote the organ $(\mathrm{Dg}=$ digestive gland, $\mathrm{Go}=$ gonad, $\mathrm{Ma}=$ mantle, $\mathrm{Gi}=$ gill, and $\mathrm{Mu}=$ adductor muscle, and $\mathrm{o}=$ each organ other than digestive gland), TR the transfer rates, DR the depuration rates, Cells $s_{t}$ the toxic cell concentration in water at time $\mathrm{t}$, and $\mathrm{K}$, a proportionality coefficient to transform cell concentration into absorbed toxin. The models were implemented and fitted to the data using the R packages deSolve [58] and FME [59].

Supplementary Materials: The following are available online at http://www.mdpi.com/2072-6651/12/11/698/s1, Figure S1: Logarithmically transformed domoic acid burden in the organs of Argopecten purpuratus during depuration experiment in laboratory conditions. Dots are the observations, triangles are the means, and the straight line is the regression line fitted to the transformed data. The equation of the line and its corresponding $\mathrm{R}^{2}$ are given at the top of each panel. The slopes of the regression lines are the depuration rate, assuming a first-order exponential depuration for each organ. Figure S2: Logarithmically transformed domoic acid burden in the organs of Argopecten purpuratus during the first three days of the depuration experiment in laboratory conditions. Dots are the observations, triangles are the means, and the straight line is the regression line fitted to the transformed data. The equation of the line and its corresponding $\mathrm{R}^{2}$ are given at the top of each panel. The slopes of the regression lines are the depuration rate, assuming a first-order exponential depuration for each organ. Figure S3: Logarithmically transformed domoic acid burden in the organs of Argopecten purpuratus during the depuration experiment in natural conditions. Dots are the observations, triangles are the means, and the straight line is the regression line fitted to the transformed data. The equation of the line and its corresponding $\mathrm{R}^{2}$ are given at the top of each panel. The slopes of the regression lines are the depuration rate, assuming a first-order exponential depuration for each organ. Figure S4: Logarithmically transformed domoic acid concentration in the organs of Argopecten purpuratus during the depuration experiment in natural conditions. Dots are the observations, triangles are the means, and the straight line is the regression line fitted to the transformed data. The equation of the line and its corresponding $\mathrm{R}^{2}$ are given at the top of each panel. The slopes of the regression lines are the depuration rate, assuming a first-order exponential depuration for each organ. Figure S5: Multi-compartment model fit to the toxin burden data obtained in the domoic acid depuration experiment in natural conditions. Small dots are the obtained data, large dots are their means, and lines are the output of the model. The model assumes that depuration takes place from the digestive gland and the kidney, after transfer of the toxin from the digestive gland to all other organs, and from those organs to the kidney. The toxin amount in the kidney and the adductor muscle were measured together ("Adductor muscle"). Figure S6. Selected chromatogram of extract of digestive gland containing domoic acid (DA) and its isomers ISO D, ISO A, and epi DA. Table S1: Pseudo-nitzschia australis concentration in the area during depuration experiment in natural conditions. The data were obtained from Invertec Ostimar and correspond to the same bay where the experiment was carried out but not to the precise location where the experiment was carried out. Table S2. Recovery of domoic acid and matrix effect in different 
tissues of Argopecten purpuratus. Table S3. Proportions of domoic acid (DA) and its isomers on selected days during depuration in laboratory experiment. Table S4. Proportions of domoic acid (DA) and its isomers on selected days during depuration in natural environment experiment.

Author Contributions: Author Contributions: Conceptualization, G.Á., J.R., and J.B.; methodology G.Á., J.R., M.A., F.Á., R.P., E.U., P.A.D., A.E.R., A.L.-R., and J.B.; investigation, G.Á., J.R., M.A., F.Á., R.P., E.U., P.A.D., A.E.R., A.L.-R., and J.B.; formal analysis, G.Á., M.A., F.Á., E.U., A.E.R., and J.B.; visualization, G.Á., P.A.D., and J.B.; writing-original draft preparation, G.Á., P.A.D., A.E.R., and J.B.; writing-review and editing, G.Á., P.A.D., A.E.R., and J.B.; software J.B.; supervision, G.Á. and J.B.; funding acquisition, G.Á. and P.A.D. All authors have read and agreed to the published version of the manuscript.

Funding: This research was funded by the "ANID + FONDEF/PRIMER CONCURSO INVESTIGACIÓN TECNOLÓGICA TEMATICO EN SISTEMAS PESQUERO ACUICOLAS FRENTE A FLORECIMIENTOS ALGALES NOCIVOS FANS IDeA DEL FONDO DE FOMENTO AL DESARROLLO CIENTÍFICO Y TECNOLÓGICO, FONDEF/ANID 2017, IT17F10002 developed within the framework of a cooperation agreement between the Consellería do Mar, Xunta de Galicia, Spain and the Universidad Católica del Norte, Chile. P. Díaz and G. Álvarez were funded by project REDI170575 from the International Cooperation Programme of the National Agency for Research and Development (ANID). Gonzalo Álvarez was funded by the ANID (ANID + PAI/CONCURSO NACIONAL INSERCION EN LA ACADEMIA CONVOCATORIA 2015, 79150008).

Acknowledgments: We have to acknowledge to Christian Tapia and Pamela Tapia (Invertec Ostimar Company) for their support.

Conflicts of Interest: The authors declare no conflict of interest.

\section{References}

1. Perl, T.M.; Bedard, L.; Kosatsky, T.; Hockin, J.C.; Todd, E.C.; McNutt, L.A.; Remis, R.S. Amnesic shellfish poisoning: A new clinical syndrome due to domoic acid. Can. Dis. Wkly. Rep. 1990, 16, 7-8. [PubMed]

2. Bates, S.; Bird, C.; Defreitas, A.; Foxall, R.; Gilgan, M.; Hanic, L.; Johnson, G.; McCulloch, A.; Odense, P.; Pocklington, R.; et al. Pennate diatom Nitzschia pungens as the primary source of domoic acid, a toxin in shellfish from eastern Prince Edward Island, Canada. Can. J. Fish. Aquat. Sci. 1989, 46, 1203-1215. [CrossRef]

3. Levin, M.; Leibrecht, H.; Ryan, J.; Van Dolah, F.; De Guise, S. Immunomodulatory Effects of Domoic Acid Differ Between In vivo and In vitro Exposure in Mice. Mar. Drugs 2008, 6, 636-659. [CrossRef] [PubMed]

4. Trainer, V.L.; Bates, S.S.; Lundholm, N.; Thessen, A.E.; Cochlan, W.P.; Adams, N.G.; Trick, C.G. Pseudo-nitzschia physiological ecology, phylogeny, toxicity, monitoring and impacts on ecosystem health. Harmful Algae 2012, 14, 271-300. [CrossRef]

5. Lelong, A.; Hegaret, H.; Soudant, P.; Bates, S.S. Pseudo-nitzschia (Bacillariophyceae) species, domoic acid and amnesic shellfish poisoning: Revisiting previous paradigms. Phycologia 2012, 51, 168-216. [CrossRef]

6. Bates, S.S.; Hubbard, K.A.; Lundholm, N.; Montresor, M.; Leaw, C.P. Pseudo-nitzschia, Nitzschia, and domoic acid: New research since 2011. Harmful Algae 2018, 79, 3-43. [CrossRef] [PubMed]

7. Álvarez, G.; Uribe, E.; Quijano-Scheggia, S.; Lopez-Rivera, A.; Mariño, C.; Blanco, J. Domoic acid production by Pseudo-nitzschia australis and Pseudo-nitzschia calliantha isolated from North Chile. Harmful Algae 2009, 8, 938-945. [CrossRef]

8. Suárez Isla, B.A.; López, A.; Hernández, C.; Clement, A.; Guzmán, L. Impacto económico de las floraciones de microalgas nocivas en Chile y datos recientes sobre la ocurrencia de veneno amnésico de los mariscos. In Floraciones Algales Nocivas en el ConoSur Americano; Sar, E.A., Ferrario, M.E., Reguera, B., Eds.; Instituto Español de Oceanografía: Madrid, Spain, 2002; pp. 259-268.

9. López-Rivera, A.; Pinto, M.; Insinilla, A.; Isla, B.S.; Uribe, E.; Álvarez, G.; Lehane, M.; Furey, A.; James, K.J. The occurrence of domoic acid linked to a toxic diatom bloom in a new potential vector: The tunicate Pyura chilensis (piure). Toxicon 2009, 54, 754-762. [CrossRef] [PubMed]

10. Díaz, P.A.; Álvarez, G.; Varela, D.; Pérez-Santos, I.; Díaz, M.; Molinet, C.; Seguel, M.; Aguilera-Belmonte, A.; Guzmán, L.; Uribe, E.; et al. Impacts of harmful algal blooms on the aquaculture industry: Chile as a case study. Perspect. Phycol. 2019, 6, 39-50. [CrossRef]

11. Cranford, P.J. Chapter 13 Scallops and marine contaminants. In Scallops: Biology, Ecology and Aquaculture; Shumway, S.E., Parsons, G.J., Eds.; Elsevier: Amsterdam, Netherlands, 2006; pp. 745-764.

12. Blanco, J.; Bermúdez de la Puente, M.; Arévalo, F.; Salgado, C.; Moroño, A. Depuration of mussels (Mytilus galloprovincialis) contaminated with domoic acid. Aquat. Living Resour. 2002, 15, 53-60. [CrossRef] 
13. Mafra, L.L.; Bricelj, V.M.; Fennel, K. Domoic acid uptake and elimination kinetics in oysters and mussels in relation to body size and anatomical distribution of toxin. Aquat. Toxicol. 2010, 100, 17-29. [CrossRef] [PubMed]

14. Mafra, L.L.; Bricelj, V.M.; Ouellette, C.; Bates, S.S. Feeding mechanics as the basis for differential uptake of the neurotoxin domoic acid by oysters, Crassostrea virginica, and mussels. Mytilus edulis. Aquat. Toxicol. 2010, 97, 160-171. [CrossRef] [PubMed]

15. Wohlgeschaffen, G.D.; Mann, K.H.; Subba Rao, D.V.; Pocklington, R. Dynamics of the phycotoxin domoic acid: Accumulation and excretion in two commercially important bivalves. J. Appl. Phycol. 1992, 4, 297-310. [CrossRef]

16. Shumway, S.E.; Cembella, A.D. The impact of toxic algae on scallop culture and fisheries. Rev. Fish. Sci. 1993, 1, 121-150. [CrossRef]

17. Álvarez, G.; Uribe, E.; Regueiro, J.; Martin, H.; Gajardo, T.; Jara, L.; Blanco, J. Depuration and anatomical distribution of domoic acid in the surf clam Mesodesma donacium. Toxicon 2015, 102, 1-7. [CrossRef]

18. Dusek Jennings, E.; Parker, M.S.; Simenstad, C.A. Domoic acid depuration by intertidal bivalves fed on toxin-producing Pseudo-nitzschia multiseries. Toxicon X 2020, 6, 100027. [CrossRef]

19. James, K.J.; Gillman, M.; Amandi, M.F.; Lopez-Rivera, A.; Puente, P.F.; Lehane, M.; Mitrovic, S.; Furey, A. Amnesic Shellfish Poisoning Toxins in Bivalve Molluscs in Ireland. Toxicon 2005, 46, 852-858. [CrossRef]

20. Douglas, D.J.; Kenchington, E.R.; Bird, C.J.; Pocklington, R.; Bradford, B.; Silvert, W. Accumulation of domoic acid by the sea scallop (Placopecten magellanicus) fed cultured cells of toxic Pseudo-nitzschia multiseries. Can. J. Fish. Aquat. Sci. 1997, 54, 907-913. [CrossRef]

21. Blanco, J. Modelling as a mitigation strategy for harmful algal blooms. In Shellfish Safety and Quality; Shumway, S.E., Rodrick, G.E., Eds.; Woodhead Publishing: Cambridge, UK, 2009; pp. 200-227.

22. Novaczek, I.; Madhyastha, M.S.; Ablett, R.F.; Donald, A.; Johnson, G.; Nijjar, M.S.; Sims, D.E. Depuration of domoic acid from live blue mussels (Mytilus edulis). Can. J. Fish. Aquat. Sci. 1992, 49, 312-318. [CrossRef]

23. Blanco, J.; Acosta, C.P.; Bermúdez de la Puente, M.; Salgado, C. Depuration and anatomical distribution of the amnesic shellfish poisoning (ASP) toxin domoic acid in the king scallop Pecten maximus. Aquat. Toxicol. 2002, 60, 111-121. [CrossRef]

24. Gilgan, M.W.; Burns, B.G.; Landry, G.J. Distribution and Magnitude of Domoic Acid Contamination of Shellfish in Atlantic Canada during 1988; Elsevier Science Publishing, Co.: Amsterdam, The Netherlands, 1990; pp. 469-474.

25. Drum, A.S.; Siebens, T.L.; Crecelius, E.A.; Elston, R.A. Domoic acid in the Pacific razor clam Siliqua patula (Dixon, 1789). J. Shellfish Res. 1993, 12, 443-450.

26. Horner, R.A.; Kusske, M.B.; Moynihan, B.P.; Skinner, R.N.; Wekell, J.C. Retention of domoic acid by Pacific razor clams, Siliqua patula (Dixon, 1789): Preliminary study. J. Shellfish Res. 1993, 12, 451-456.

27. Blanco, J.; Acosta, C.P.; Mariño, C.; Muñíz, S.; Martín, H.; Moroño, A.; Correa, J.; Arévalo, F.; Salgado, C. Depuration of domoic acid from different body compartments of the King Scallop Pecten maximus grown in raft culture and natural bed. Aquat. Living Resour. 2006, 19, 257-265. [CrossRef]

28. Hess, P.; Brown, N.A.; Bates, L.A.; Turriff, J.J.; Howard, F.G.; Moffat, C.F. A comparison of domoic acid in scallop (Pecten maximus) gonads processed by FRS Ml whith those prepared by a commercial processor. Fish. Res. Serv. 2000, 30, 1-6.

29. Campbell, D.A.; Kelly, M.S.; Busman, M.; Wiggins, E.; Fernandes, T.F. Impact of preparation method on gonad domoic acid levels in the scallop, Pecten maximus (L.). Harmful Algae 2003, 2, 215-222. [CrossRef]

30. Campbell, D.A.; Kelly, M.S.; Busman, M.; Bolch, C.J.; Wiggins, E.; Moeller, P.D.R.; Morton, S.L.; Hess, P.; Shumway, S.E. Amnesic shellfish poisoning in the king scallop, Pecten maximus, from the west coast of Scotland. J. Shellfish Res. 2001, 20, 75-84.

31. Bogan, Y.M.; Bender, K.; Hervas, A.; Kennedy, D.J.; Slater, J.W.; Hess, P. Spatial variability of domoic acid concentration in King Scallops Pecten maximus off the Southeast Coast of Ireland. Harmful Algae 2007, 6, 1-14. [CrossRef]

32. Bogan, Y.M.; Harkin, A.L.; Gillespie, J.; Kennedy, D.J.; Hess, P.; Slater, J.W. The Influence of Size on Domoic Acid Concentration in King Scallop, Pecten maximus (L.). Harmful Algae 2007, 6, 15-28. [CrossRef]

33. Bogan, Y.M.; Kennedy, D.J.; Harkin, A.L.; Gillespie, J.; Vause, B.J.; Beukers-Stewart, B.D.; Hess, P.; Slater, J.W. Variation in domoic acid concentration in King Scallop (Pecten maximus) from fishing grounds around the Isle of Man. Harmful Algae 2007, 6, 81-92. [CrossRef] 
34. Blanco, J.; Cano, J.; Marino, M.D.C.; Campos, M.J. Effect of Phytoplankton Containing Paralytic Shellfish and Amnesic Shellfish Toxins on the Culture of the King Scallop Pecten maximus in Málaga (Se Spain). Aquat. Living Resour. 2006, 19, 267-273. [CrossRef]

35. EU. Commission Decision of 15 March 2002 establishing special health checks for the harvesting and processing of certain bivalve molluscs with a level of amnesic shellfish poison (ASP) exceeding the limit laid down by Council Directive 91/492/EEC. Off. J. Eur. Communities 2002, 75, 65-66.

36. Paseiro, P. Informe del Comité Científico de la Agencia Española de Seguridad Alimentaria y Nutrición (AESAN) sobre los criterios de seguridad aplicables al contenido de ácido domoico en la vieira (Pecten maximus) para su recolección. Rev. Del Com. Científico 2009, 10, 41-52.

37. Alamo, V.; Valdivieso, V. Lista sistemática de moluscos marinos del Perú. Bol. Inst. Mar. Perú, Callao. 1987. Available online: http://www.scielo.org.pe/scielo.php?script=sci_arttext\&pid=S1727-99332003000200012 (accessed on 3 November 2020).

38. Sanzana, J. Estudios Preliminares del Ostión (Chlamys Purpurata, Lamarck, 1819) de la zona de Valparaíso; Universidad Católica de Valparaíso: Valparaíso, Chile, 1978.

39. Wolff, M.; Taylor, M.H.; Mendo, J.; Yamashiro, B. A catch forecast model for the Peruvian scallop (Argopecten purpuratus) based on estimators of spawning stock and settlement rate. Ecol. Model. 2007, 209, 333-341. [CrossRef]

40. Valenzuela, A.; Yáñez, C.G.; Golusda, C. The scallop from the chilean north (Argopecten purpuratus), A food with a high nutritional value. Rev. Chil. Nutr. 2011, 38, 148-155.

41. Mendo, J.; Wolff, M.; Mendo, T.; Ysla, L. Scallop Fishery and Culture in Peru. In Scallops: Biology, Ecology, Aquaculture, and Fisheries; Shumway, S.E., Parson, G.J., Eds.; Elsevier: Amsterdam, The Netehrlands, 2016; Volume 40, pp. 1089-1109.

42. Wolff, M. Population dynamics of the Peruvian scallop Argopecten purpuratus during the El Niño phenomenon of 1983. Can. J. Fish. Aquat. Sci. 1987, 44, 1684-1691. [CrossRef]

43. Kluger, L.C.; Taylor, M.H.; Wolff, M.; Stotz, W.; Mendo, J. From an open-access fishery to a regulated aquaculture business: The case of the most important Latin American bay scallop (Argopecten purpuratus). Rev. Aquac. 2019, 11, 187-203. [CrossRef]

44. von Brand, E.; Abarca, A.; Merino, G.; Stotz, W. Scallop Fishery and Aquaculture in Chile: A History of Developments and Declines. In Scallops: Biology, Ecology, Aquaculture and Fisheries; Shumway, S.E., Parson, G.J., Eds.; Elsevier: Amsterdam, The Netherlands, 2016; Volume 40, pp. 1047-1071.

45. Barber, B.; Blake, N. Reproductive Physiology. In Scallops: Biology, Ecology, Aquaculture and Fisheries; Shumway, S.E., Parson, G.J., Eds.; Elsevier: Amsterdam, The Netherlands, 2016; pp. 253-299.

46. Bricelj, V.M.; Cembella, A.D.; Laby, D. Temperature effects on kinetics of paralytic shellfish toxin elimination in Atlantic surfclams. Spisula solidissima. Deep-Sea Res. Part Ii: Top. Stud. Oceanogr. 2014, 103, 308-317. [CrossRef]

47. Peck, L.S. Temperature and basal metabolism in two Antarctic marine herbivores. J. Exp. Mar. Biol. Ecol. 1989, 127, 1-12. [CrossRef]

48. Grizzle, R.E.; Bricelj, V.M.; Shumway, S.E. Physiological ecology of Mercenaria mercenaria. In Biology of the Hard Clam; Kraeuter, J.N., Castagna, M., Eds.; Elsevier: New York, NY, USA, 2001; pp. 305-382.

49. Mafra, L., Jr.; Bricelj, V.; Ouellette, C.; Léger, C.; Bates, S. Mechanisms contributing to low domoic acid uptake by oysters feeding on Pseudo-nitzschia cells. I. Filtration and pseudofeces production. Aquat. Biol. 2009, 6, 201-212. [CrossRef]

50. Beninger, P.; Le Pennec, M. Scallop structure and function. In Scallops: Biology, Ecology, Aquaculture and Fisheries; Shumway, S.E., Parson, G.J., Eds.; Elsevier: Amsterdam, The Netherlands, 2016; pp. 85-158.

51. Eggermont, M.; Cornillie, P.; Dierick, M.; Adriaens, D.; Nevejan, N.; Bossier, P.; Van den Broeck, W.; Sorgeloos, P.; Defoirdt, T.; Declercq, A.M. The blue mussel inside: 3D visualization and description of the vascular-related anatomy of Mytilus edulis to unravel hemolymph extraction. Sci. Rep. 2020, 10, 6773. [CrossRef]

52. Jones, T.O.; Whyte, J.N.C.; Townsend, L.D.; Ginter, N.G.; Iwama, G.K. Effects of domoic acid on haemolimph $\mathrm{pH}, \mathrm{pCO} 2$, and $\mathrm{pO} 2$ in the Pacific oyster, Crassostrea gigas and the California mussel. Mytilus californianus. Aquat. Toxicol. 1995, 31, 43-55. [CrossRef]

53. Utermöhl, H. Zur Vervollkommnung der quantitativen Phytoplankton-Methodik. SIL Commun. 1953-1996 2017, 9, 1-38. [CrossRef] 
54. Navarro, J.M.; Gonzalez, C.M. Physiological responses of the Chilean scallop Argopecten purpuratus to decreasing salinities. Aquaculture 1998, 167, 315-327. [CrossRef]

55. Olenina, I.; Hajdu, S.; Edler, L.; Andersson, A.; Wasmund, N.; Busch, S.; Göbel, J.; Gromisz, S.; Huseby, S.; Huttunen, M.; et al. Biovolumes and Size-Classes of Phytoplankton in the Baltic Sea; Helsinki Commission Baltic Marine Environment Protection Commission: Helsinki, Finland, 2006; 144p.

56. Quilliam, M.A.; Xie, M.; Hardstaff, W.R. Rapid Extraction and Cleanup for Liquid Chromatographic Determination of Domoic Acid in Unsalted Seafood. J. AOAC Int. 1995, 78, 543-554. [CrossRef]

57. Regueiro, J.; Martin-Morales, E.; Álvarez, G.; Blanco, J. Sensitive determination of domoic acid in shellfish by on-line coupling of weak anion exchange solid-phase extraction and liquid chromatography-diode array detection-tandem mass spectrometry. Food Chem. 2011, 129, 672-678. [CrossRef] [PubMed]

58. Soetaert, K.; Petzoldt, T.; Setzer, R.W. Solving Differential Equations in R: Package deSolve. J. Stat. Softw. 2010, 33. [CrossRef]

59. Soetaert, K.; Petzoldt, T. Inverse Modelling, Sensitivity and Monte Carlo Analysis in R Using Package FME. J. Stat. Softw. 2010, 33. [CrossRef]

Publisher's Note: MDPI stays neutral with regard to jurisdictional claims in published maps and institutional affiliations.

(C) 2020 by the authors. Licensee MDPI, Basel, Switzerland. This article is an open access article distributed under the terms and conditions of the Creative Commons Attribution (CC BY) license (http://creativecommons.org/licenses/by/4.0/). 